Michą GABRIEL WoźNIAK

Uniwersytet Ekonomiczny, Kraków

Uniwersytet Rzeszowski

\title{
Zmiany strukturalne gospodarki Polski po 1990 roku
}

Powszechnie przyjmuje się, że gospodarka przemysłowa charakterystyczna dla XX wieku zostanie wyparta w XXI wieku w wyniku informatyzacji gospodarowania i życia społecznego. Jej miejsce zajmie gospodarka oparta na wiedzy, wykorzystująca powszechnie technologie informatyczno-telekomunikacyjne, a inwestowanie w człowieka stanie się główną siłą napędową zmian strukturalnych i rozwoju społeczno-gospodarczego. W Polsce i w innych krajach posocjalistycznych przemiany te są wymuszane w wyniku transformacji systemu ekonomicznego, demokratyzacji i przenikania w ślad za tym reguł kapitalizmu globalnego. Niezwykle ważnym czynnikiem przemian strukturalnych jest również integracja z Unią Europejską.

Celem tego opracowania jest zbadanie, czy zmiany struktury własnościowej gospodarki Polski rokują nadzieję na odpowiadającą wyzwaniom kapitalizmu globalnego konwergencję struktury aparatu wytwórczego, produkcji i zatrudnienia, umożliwiającą uzyskanie przewagi konkurencyjnej, a w jej wyniku zmniejszenie dystansu rozwojowego w rozsądnym przedziale czasowym.

\section{ROZWÓJ SEKTORA PRYWATNEGO W LATACH 1990-2006}

W spadku po socjalizmie pozostała w Polsce zniekształcona struktura podmiotowa przedsiębiorstw z dominacją dużych przedsiębiorstw państwowych, niedorozwojem sektora małych i średnich przedsiębiorstw (MSP) i sektora prywatnego. Ten nieefektywny przemysłowy sektor nieprywatny charakteryzował się wyjątkowo wysokim stopniem dekapitalizacji aparatu wytwórczego (50-85\%), który dostarczał w olbrzymiej większości produkcję niedostosowaną do potrzeb otwartych rynków. Wymuszenie efektywności ekonomicznej i aktywnych dostosowań w zakresie struktury produkcji i aparatu wytwórczego poprzez szybką prywatyzację bez równoczesnego szybkiego wzrostu liczby nowych przedsiębiorstw groziłoby ujemnymi konsekwencjami dla efektywności ekonomicznej, przeciwdziałania bezrobociu i konwergencji w kierunku struktury podmiotowej właściwej dla rozwiniętej gospodarki rynkowej. Wyłonił się w związku z tym problem zmian instytucjonalnych koniecznych do tworzenia nowych przedsiębiorstw. 
W Polsce rozwiązanie tego problemu zainicjowano już pod koniec lat 80. dzięki regulacjom ustawowym. Drobna prywatna przedsiębiorczość, prywatne rodzinne gospodarstwa rolne, prywatne rzemiosło i firmy polonijno-zagraniczne już od 1988 r. zostały wzmocnione mocą rozporządzenia Rady Ministrów tzw. spółkami nomenklaturowymi. Dzięki temu otwarto drogę do tworzenia prywatnych spółek na bazie majątku przedsiębiorstw państwowych poprzez dzierżawę lub przekazywanie majątku tych przedsiębiorstw osobom związanym z kadrą kierowniczą przedsiębiorstw. Uruchomiony został w ten sposób proces samouwłaszczenia działaczy partyjnych i państwowych różnych szczebli (zamiany władzy na własność). Ten mechanizm prywatyzacji nie stwarzał jednak możliwości transferu praw własności. Otworzył jednak drogę nierównego dostępu do informacji, kredytów, gwarancji rządowych, a także surowców i materiałów, które w warunkach niedoborów były nieosiagalne dla innych podmiotów. Ta zbyt łatwa droga bogacenia stała się zaczynem wyłaniania się kapitalizmu państwowego i splatania interesów polityków i przedsiębiorców, co z czasem przyczyniło się do upowszechnienia przedsięwzięć na pograniczu prawa i korupcji.

Aż do jesieni 1990 r. wszelkie przekształcenia własnościowe przedsiębiorstw państwowych mogły się dokonywać na podstawie ustawy o przedsiębiorstwach państwowych z 1981 r. poprzez wnoszenie aktywów netto przedsiębiorstw do spółek.

Nierównoprawne traktowanie przez prawo „nowych przedsiębiorstw prywatnych i administrowanie przez państwo" wejścia na rynek z biznesem nie stwarzało jednak możliwości do formowania się obszarów sprawnych rynków. Pomimo tego ten spontaniczny rozwój nowego sektora prywatnego miał ogromny wpływ na późniejsze przekształcenia własnościowe, szybki, spontaniczny i szeroki rozwój nowych przedsiębiorstw prywatnych i efekty ekonomiczne polskiego procesu urynkowienia.

Z powodu rozmaitych luk w zakresie statystyk dotyczących sektora MSP oraz zmian w czasie kryteriów klasyfikacji podmiotów gospodarczych nie dysponujemy precyzyjnymi informacjami pozwalającymi właściwie ocenić rolę tworzenia nowych przedsiębiorstw prywatnych w procesie konwergencji ekonomicznej. Można jedynie wskazać na zmiany udziału całego sektora prywatnego w wybranych wskaźnikach ekonomicznych (tab. 1).

Tab. 1. Udział sektora prywatnego w wybranych wskaźnikach ekonomicznych w latach 1990-2006, w \%

\begin{tabular}{|l|c|c|c|c|c|c|c|}
\hline \multicolumn{1}{|c|}{ Wyszczególnienie } & 1990 & 1993 & 1997 & 2000 & 2004 & 2005 & 2006 \\
\hline W liczbie pracujących ogółem (na 31 XII) & 48,9 & 58,9 & 68,2 & 72,1 & 70,9 & 71,6 & 72,2 \\
\hline Udział w PKB & 30,9 & 47,5 & 58,7 & 61,2 & 66,2 & 66,2 & b.d. \\
\hline Udział w produkcji sprzedanej przemysłu & 18,3 & 34,5 & 64,2 & 71,3 & 80,9 & 82,4 & 84,2 \\
\hline Udział w sprzedaży detalicznej & 63,7 & 89,1 & 94,4 & 95,1 & 98,4 & 98,6 & 98,6 \\
\hline Udział w nakładach inwestycyjnych & 41,3 & 42,9 & 53,4 & 65,2 & 68,1 & 65,1 & 65,1 \\
\hline Udział w wartości importu & 14,4 & 59,8 & 82,5 & 84,2 & 91,7 & 90,3 & 95,7 \\
\hline Udział w wartości eksportu & 4,9 & 44,0 & 74,3 & 83,6 & 88,1 & 87,4 & 93,2 \\
\hline
\end{tabular}

Źródło: Roczniki Statystyczne 1991-2006, GUS, Warszawa 2006, Mały Rocznik Statystyczny, GUS, Warszawa 2007 
Istnieją szacunki wskazujące, że w 1989 roku powstało prawie 400 tys. nowych przedsiębiorstw, a w latach 1990-1992 rocznie przybywało średnio 250-300 tys. zarejestrowanych spółek cywilnych (Chmiel, 1999, s. 15). W następnych latach dynamika przyrostu liczby nowych przedsiębiorstw uległa spowolnieniu. W sumie od 1990 r. do czasu wstapienia do UE (2004) przybyło w Polsce ponad 3 mln nowych przedsiębiorstw prywatnych.

Oryginalnym zjawiskiem początkowych lat transformacji w Polsce była tzw. mała prywatyzacja. W jej wyniku nastappił lawinowy proces przejmowania w latach 1990-1991 przez osoby fizyczne sklepów oraz innych nieruchomości komunalnych w transporcie i budownictwie, głównie poprzez kontrakty dzierżawne. Z reguły kontrakty te były zawierane $\mathrm{z}$ dotychczasowymi pracownikami. Jedynie w odniesieniu do kilku procent obiektów prywatyzowanych stosowano przetargi otwarte bądź konkursy ofert, w których mogli uczestniczyć wszyscy zainteresowani.

W latach 1992-1994 nastąpiło wyraźne zwolnienie dynamiki tworzenia nowych przedsiębiorstw prywatnych. Przyspieszenie wzrostu gospodarczego przyczyniło się do ponownego dynamicznego wzrostu liczby nowo zakładanych przedsiębiorstw prywatnych w latach 1996-1999.

Najpopularniejszą formą realizacji idei akcjonariatu pracowniczego w Polsce był leasing majątku przedsiębiorstwa państwowego. Ta ścieżka prywatyzacji okazała się specyfiką polskiej denacjonalizacji w początkowych latach transformacji. Do połowy 1994 r. aż $75 \%$ wszystkich przypadków prywatyzacji bezpośredniej realizowano za pomocą leasingu pracowniczego.

Od drugiej połowy lat 90. zaczęły się ujawniać symptomy kryzysu leasingu pracowniczego. Rentowność spółek pracowniczych okazywała się coraz częściej niższa niż przedsiębiorstw prywatyzowanych kapitałowo lub z udziałem kapitału zagranicznego. Wobec zaostrzającej się konkurencji w związku z rozprzestrzenianiem się skutków lokalnych kryzysów finansowych $\mathrm{w}$ gospodarce światowej spółki pracownicze obciążone ratami leasingowymi drastycznie traciły kondycję ekonomiczno-finansową, możliwości modernizacji, szanse rozwoju i pozycję konkurencyjną. Wyłonił się w związku z tym problem poszukiwania inwestora strategicznego. Od $2000 \mathrm{r}$. rozpoczął się proces wtórnej prywatyzacji i odkupywania w związku z tym akcji pracowniczych, w którym brała zwykle udział kadra zarządzająca wyższego szczebla danej spółki. W wyniku tego procesu również w Polsce próba zbudowania „kapitalizmu ludowego” poprzez upowszechnienie własności wśród pracowników za pomocą leasingu nie spełniła pokładanych w niej nadziei i okazała się jedynie tymczasowa, wydłużoną drogą do własności prywatnej zdolnej do sprostania konkurencji w warunkach globalnego kapitalizmu.

Inną próbą upowszechnienia własności był program Narodowych Funduszy Inwestycyjnych (NFI), który został oparty na idei akcjonariatu obywatelskiego. W ocenie ekspertów ekonomiczne cele prywatyzacji za pomocą NFI nie zostały zrealizowane efektywnie. Wprawdzie spółki parterowe zwykle nie wykazywały pogorszenia efektywności ekonomicznej, to jednak nie dostarczały akcjonariuszom wartości dodanej. Nie notowano również zasadniczej poprawy w zakresie restrukturyzacji spółek parterowych.

Struktura własnościowa spółek parterowych była niespójna z zasadniczymi celami NFI; Skarb Państwa zachował bowiem 25\% udziałów, 15\% akcji obejmowali pracownicy, $27 \% \mathrm{w}$ równych ułamkowych wielkościach wszystkie pozostałe NFI, zaś fundusz wyznaczony do restrukturyzacji spółki parterowej stanowił jedynie 33\% akcji, co formalnie czyniło go mniejszościowym udziałowcem, nierzadko pozbawionym możliwości decydowania 
o kierunkach restrukturyzacji, jeśli inwestor zewnętrzny zdołał odkupić akcje pracownicze, niektóre pakiety mniejszościowe od Skarbu Państwa czy też poprzez inwestycje giełdowe. Program powszechnej prywatyzacji przyniósł też niewielkie efekty pod względem upowszechnienia własności oraz rozwoju rynku kapitałowego. Obywatele masowo pozbywali się swych udziałów w NFI.

Osiemnastoletnie doświadczenia w zakresie transformacji stosunków własnościowych w Polsce dowodzą, że możliwa jest konwergencja praw własności w kierunku istniejących w rozwiniętych krajach kapitalistycznych i osiagnnięcie zbliżonej struktury podmiotowej gospodarki. W 2005 r. udział sektora prywatnego w większości sekcji gospodarki był w Polsce zaledwie o kilka procent niższy niż w rozwiniętych krajach Europy Zachodniej i oscyluje wokół 90\%. Zredukowanie własności państwowej do 10\% wymaga sprywatyzowania około 350-450 przedsiębiorstw. Wydaje się to wykonalne w ciągu najbliższych kilku lat.

W przychodach i zatrudnieniu największych 1095 przedsiębiorstw kapitał zagraniczny partycypuje w ponad $60 \%$. Kapitał zagraniczny zdołał jednak zapewnić nieco wyższą wydajność pracy niż krajowi właściciele. W tym samym zbiorze największych przedsiębiorstw $70 \%$ stanowią nowe podmioty, które mają co najmniej o $1 / 4$ większą wydajność pracy od sprywatyzowanych przedsiębiorstw (Bałtowski, Miszewski, 2006, s. 248-254).

W obszarze istniejącej własności państwowej trudnym, lecz niezwykle ważnym problemem jest wdrożenie skutecznego systemu nadzoru właścicielskiego, który zapewni efektywne wykorzystanie kapitału inwestorów, stosowanie norm etyki biznesu, odpowiedzialność zarządów wobec akcjonariuszy i wspólników oraz zagwarantuje długofalową strategię przetrwania na otwartych rynkach. Do najbardziej znaczących błędów prywatyzacji należy zaliczyć brak długofalowej wizji prywatyzacji, zawierającej również listę przedsiębiorstw i sektorów strategicznych, w których państwo powinno mieć dominującą pozycję lub wyłączność. Innym fundamentalnym błędem prywatyzacji jest niedostateczna troska o jakość prawa chroniącego i promującego własność prywatną oraz regulującego nadzór właścicielski państwa wobec podmiotów sektora publicznego.

Konflikty społeczne, społeczny opór i wysokie bezrobocie są nieuchronnym ubocznym produktem transformacji stosunków własnościowych. Choć nie można ich uniknąć, to jednak możliwe jest ich zredukowanie poprzez dobór odpowiedniej metody prywatyzacji oraz wysoką jakość prawa gwarantującego jednakową dla wszystkich swobodę wejścia z biznesem na rynek i uniemożliwiającego korzystanie z uprzywilejowanej pozycji różnych grup interesów w procesie prywatyzacji.

\section{ZMIANY STRUKTURY RODZAJOWEJ PRODUKCJI}

Urynkowienie gospodarki i prywatyzacja spowodowały, iż podmioty gospodarcze stanęły przed koniecznością poprawy efektywności działalności oraz dostosowania jej profilu do potrzeb odbiorców. Procesy te, w miarę ich rozwoju, uruchamiały bodźce dla zmian ilościowych i jakościowych w gospodarce, które w początkowej fazie transformacji przebiegały w sposób niezwykle intensywny i burzliwy, aby w kolejnych latach przybrać formę procesów o charakterze ewolucyjnym, będących stałym elementem funkcjonowania gospodarek kapitalistycznych. 
Wobec dominacji sektora nieprywatnego latach 1989-1991 zmiany w strukturze wytwarzania miały charakter dostosowań negatywnych. Wyrażały się one w obniżaniu poziomu produkcji w wielu działach przemysłu i upadłości części przedsiębiorstw. Brak zdolności dostosowawczych podmiotów nieprzywykłych do funkcjonowania na otwartych rynkach bez parasola ochronnego państwa był spowodowany wielorakimi przyczynami. Najważniejsze $\mathrm{z}$ ich to: szok transformacyjny i utrata $\mathrm{w}$ jego wyniku zdolności rozwojowej sektora państwowego, zbyt restrykcyjna polityka stabilizacyjna i brak wizji zmian strukturalnych kolejnych ekip rządowych oraz zmiana międzynarodowych uwarunkowań ekonomicznych w wyniku upadku RWPG, Układu Warszawskiego i ZSRR (Lipowski 1994, s. 78). „Recesja transformacyjna” oznaczała nie tyle koniunkturalne obniżenie popytu, lecz procesy ujawnienia produkcji „niechcianej” (szacowanej nawet na $40 \%$ produkcji przemysłowej) i wdrożenia rynkowego mechanizmu cenowego, które radykalnie zmieniły relacje nakładów i wyników, ujawniając skalę nieefektywności ekonomicznej dotychczasowej struktury produkcji. Spadek aktywności gospodarczej dotknął zatem w głównej mierze nieefektywne obszary wytwórczości, ale skutkiem ubocznym kryzysu było także ograniczenie produkcji w sektorach uznanych za rozwojowe (np. elektromaszynowym). W tak zmiennym otoczeniu wewnętrznym i zewnętrznym zmiany asortymentowej struktury produkcji przebiegały W różnych kierunkach, a tendencje pozytywne (np. ograniczenie produkcji hutnictwa) przebiegały równolegle $\mathrm{z}$ tendencjami negatywnymi (np. przejściowy wzrost udziału górnictwa w produkcji przemysłowej). Podstawową formą reakcji podmiotów na sytuację kryzysową przy ograniczonych zdolnościach inwestycyjnych było „uszczuplanie” przedsiębiorstw, rezygnacja z nierentownych działów i racjonalizacja zatrudnienia (Kaczmarek, P. Krzemiński, P. Litwa, W. Szymla 2005, s. 102).

Recesja transformacyjna została powstrzymana w 1993 r. Od tego czasu aż do chwili obecnej obserwuje się okresowe zmiany dynamiki PKB, jednakże na tle nieprzerwanej tendencji wzrostowej produkcji i dochodu. W tym okresie można wyróżnić trzy fazy wzrostu produkcji: w latach 1994-1997 fazę szybkiego wzrostu, fazę spowolniania dynamiki gospodarczej w latach 1998-2003 oraz okres ponownego wzrostu dynamiki PKB zapoczątkowany w roku 2004. Podobne fazy dynamiki, chociaż o znacznie wyższej zmienności, można było zaobserwować w odniesieniu do produkcji sprzedanej przemysłu. Ta wyższa zmienność dynamiki produkcji przemysłu niż PKB była wynikiem wysokiej wrażliwości tego sektora na zmiany czynników koniunkturalnych. W okresie dekoniunktury jej spadek był silniejszy niż PKB, zaś w okresach ożywienia dynamika przemysłu była wyraźnie większa niż dynamika PKB.

Wzrost wartości produkowanych dóbr i usług nie przebiegał równomiernie w poszczególnych sektorach gospodarki. Wartość dodana wytworzona w sektorze rolnym pozostawała w latach 1992-2005 na zbliżonym poziomie (w cenach stałych), podobnie jak rozmiary produkcji przemysłowej. Dynamicznie rosła natomiast wartość dodana wytworzona w sektorze usług. Wypadkową tych tendencji był systematyczny spadek udziału rolnictwa, stabilizacja udziału przemysłu w wytwarzaniu PKB oraz systematyczny wzrost udziału sektora usług, z ok. 50\% w 1992 do prawie 64\% w 2005 (ryc. 1).

W statystykach międzynarodowych udział sektora usług w gospodarce jest uznawany za wyznacznik poziomu jej rozwoju. Zaobserwowane w Polsce zmiany struktury sektorowej produkcji świadczą o konwergencji struktury sektorowej produkcji do rozwiniętych gospodarek rynkowych, aczkolwiek dystans dzielący Polskę od najwyżej rozwiniętych krajów jest jeszcze wyraźny (ryc. 2). Ocena zaawansowania przemian strukturalnych w Polsce na pod- 
stawie powyższych zmian sektorowych musi być jednakże ostrożna, ze względu na specyfikę przebiegu procesów dostosowawczych do tego prowadzących. Naturalny proces serwicyzacji obserwowany w krajach rozwiniętych ma swoje źródło w materialnej sferze gospodarki w powiązaniu ze wzrostem przeciętnego poziomu życia ludności. Zmiany jakościowe w przemyśle, głównie w postaci postępu technologicznego i organizacyjnego, prowadzą do wzrostu produktywności w przemyśle, a jednocześnie podnoszą dochód narodowy i zmieniają strukturę popytu. Są to zatem synchroniczne zmiany podażowej strony gospodarki (spadek zapotrzebowania na siłę roboczą w przemyśle) i popytowej (zwiększenie zapotrzebowania na usługi). Jest to zatem skutek ogólnego rozwoju społeczno-gospodarczego i dobrobytu społecznego. W Polsce proces ten przebiegał w sposób nieco odbiegający od tego schematu. Przyczyną zmian strukturalnych w tym obszarze było ograniczenie udziału przemysłu W wyniku przemian transformacyjnych i ukierunkowania produkcji na rzeczywiste potrzeby rynku w znacznym stopniu w oderwaniu od przeciętnego poziomu dochodów ludności, choć w pewnych obszarach zmiany te służyły poprawie jakości życia.

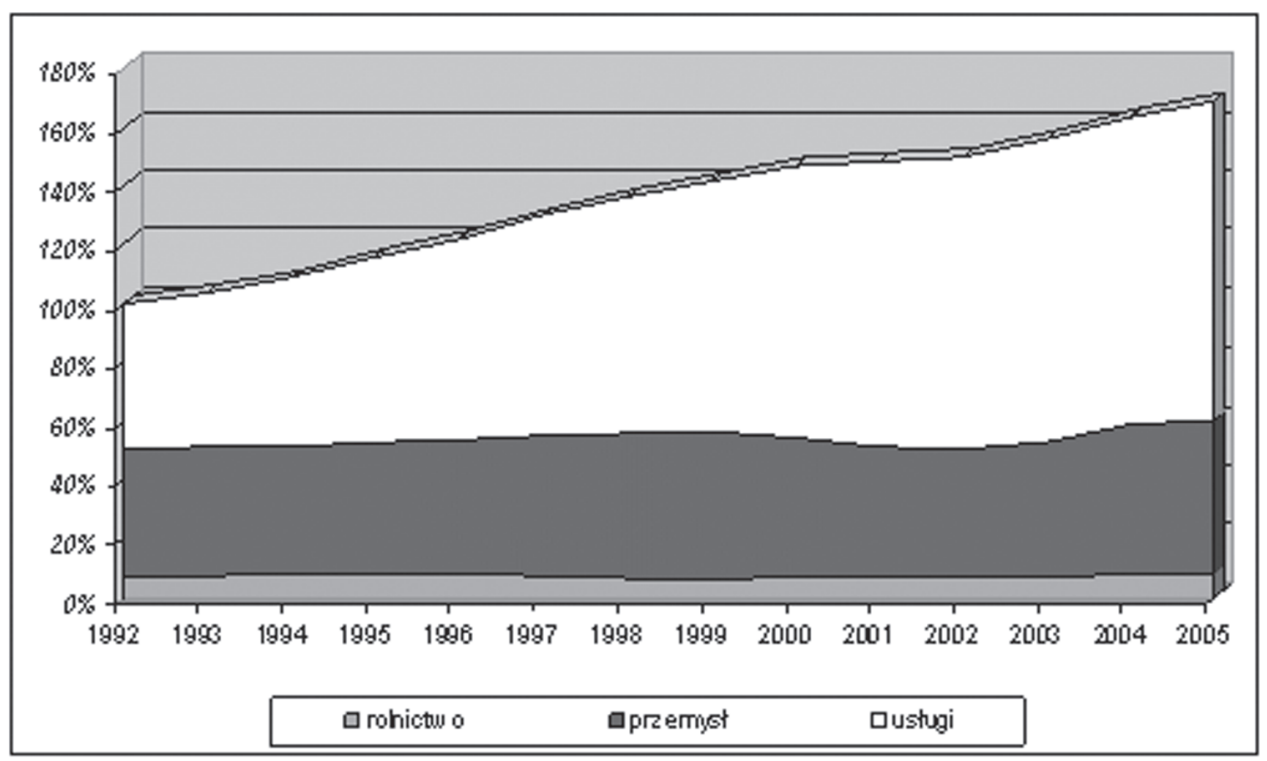

Ryc. 1. Dynamika i struktura wartości dodanej brutto w gospodarce polskiej w latach 1992-2005 (ceny stałe)

Źródło: Roczniki Statystyczne RP, GUS, Warszawa, wydania z lat 1993-2006 (tablice „Dynamika produktu krajowego brutto, ceny stałe)

Jednym z istotnych procesów składających się na transformację gospodarki była zmiana struktury produkcji i modernizacja przemysłu. W latach 1989-1991 zmiana struktury produkcji przemysłowej dokonywała się głównie za sprawą spadku produkcji w przestarzałych branżach, na skutek upadku znacznej liczby przedsiębiorstw państwowych. Począwszy od 1992 r. wartość produkcji sprzedanej w większości dziedzin wytwórczości ponownie osiągnęła kierunek wzrostowy. Nierównomierna dynamika wzrostu produkcji w poszczególnych sekcjach i działach przemysłu stała się źródłem zmian strukturalnych. 


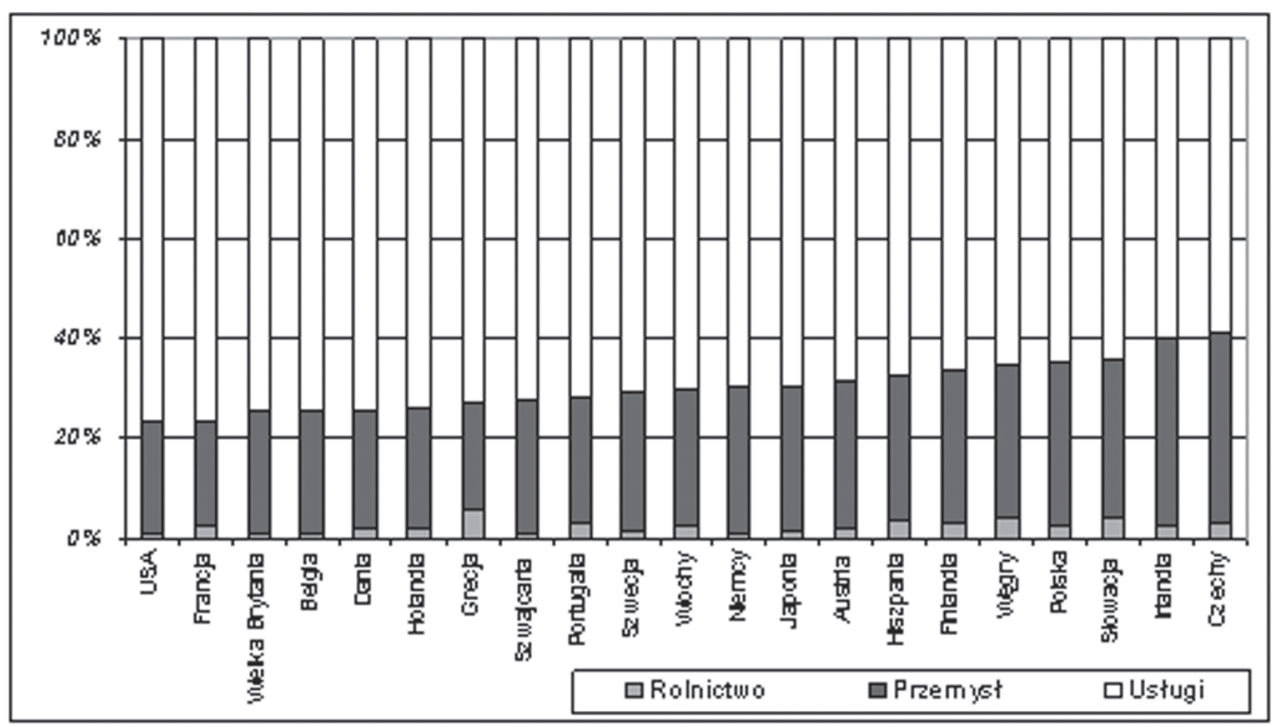

Ryc. 2. Udział poszczególnych sektorów w tworzeniu wartości dodanej brutto w Polsce i wybranych krajach w 2004 r.

Źródło: OECD in Figures 2006-2007, OECD Publications, Paris 2006, s. 16

W latach 1992-2005 obserwowano generalną tendencję spadku udziału górnictwa w produkcji przemysłowej. Wynikało to z tego, że okresach przyspieszonego wzrostu gospodarczego sektor wydobywczy charakteryzował się stałym poziomem produkcji, natomiast w okresie spowolnienia w latach 1998-2003 nastapiło wyraźne obniżenie sprzedaży tej branży. Łączne skutki tych zmian oraz głębokiej recesji górnictwa na początku lat 90. doprowadziły do istotnego spadku udziału górnictwa w strukturze produkcji sprzedanej przemysłu na rzecz przemysłu przetwórczego.

W obrębie przetwórstwa przemysłowego względnie słabą dynamiką wzrostu, skutkującą spadkiem udziału w strukturze przemysłu, odnotowało przede wszystkim hutnictwo, produkcja koksu i rafinacja ropy naftowej oraz przemysł włókienniczy i odzieżowy. Szybszą od przeciętnej dynamiki wzrostu charakteryzowała się natomiast produkcja wyrobów z gumy i tworzyw sztucznych, wyrobów metalowych, samochodów, sprzętu radiowo-telewizyjnego oraz maszyn biurowych i komputerów. Zmiany relacji cen pomiędzy różnymi produktami sprawiły, że skutki zmian realnego poziomu produkcji w poszczególnych branżach nie w każdym przypadku przełożyły się proporcjonalnie na zmianę udziału w wartości sprzedanej przemysłu. Pomimo zniekształceń procesów realnych zmianami cen, należy podkreślić, że obserwuje się wyraźny proces modernizacji polskiego przemysłu w kierunku struktur właściwych krajom wysoko rozwiniętym. Jeżeli do owych tendencji dodać niewątpliwą poprawę organizacji i zarządzania w sektorze przedsiębiorstw, jak również pozytywny wpływ wdrażanych zmian na jakość środowiska (Macias, 2006, s. 26), zaznacza się wyraźnie proces konwergencji struktury produkcji do modelu właściwego dla rozwiniętej gospodarki rynkowej. Należy jednak podkreślić, iż podobne tendencje ujawniły się w większości krajów świata. 
W gospodarce postindustrialnej modernizacja jest wyzwaniem konkurencyjnym, ale równocześnie swego rodzaju pościgiem za ruchomym celem. Jej efekty należy oceniać nie tylko poprzez konfrontację struktury produkcji z osiagnięciami innych. Priorytetem w strategii budowy gospodarki opartej na wiedzy nie tylko w krajach rozwiniętych, ale również gospodarek poszukujących skutecznych metod nadrabiania zaległości rozwojowych jest natomiast rozwój przemysłów wysokiej techniki, w szczególności z zakresu produkcji dóbr finalnych, gwarantujący wysoką konkurencyjność gospodarki (Turowski 2006, s. 96). Niestety, analiza struktury produkcji polskiego przemysłu w podziale na sektory o różnym poziomie zaawansowania technologicznego (tab. 2) nie potwierdza odpowiadającego wyzwaniom rozwojowym GOW procesu konwergencji technologicznej. Pomimo pozytywnych tendencji w wybranych dziedzinach nie obserwuje się ogólnego trendu wzrostowego w zakresie produkcji dóbr o wysokim „nasyceniu” wiedzą. W ostatnim dziesięcioleciu struktura ta uległa niewielkim zmianom, które sprowadzały się głównie do nieznacznego spadku udziału dóbr o najniższym poziomie zaawansowania technologicznego na rzecz artykułów zaliczanych do średnio-niskiej techniki. Modernizacja technologiczna polskiego przemysłu odbywa się przede wszystkim w obrębie produkcji dóbr standardowych i ogranicza się do poprawy jakości i wydajności, bez istotnego rozwoju nowych dziedzin przemysłu.

Tab. 2. Udział przemysłów według zaawansowania technologicznego

w produkcji sprzedanej polskiego przemysłu oraz w eksporcie i imporcie w latach 1995-2005

\begin{tabular}{|l|c|c|c|c|}
\hline \multicolumn{1}{|c|}{ Rok } & 1995 & 2000 & 2004 & \multicolumn{1}{c|}{2005} \\
\hline udział w produkcji sprzedanej przemysłu: & 100 & 100 & 100 & 100 \\
\hline wysoka technika & 3,3 & 5,6 & 4,5 & 4,5 \\
\hline średnio-wysoka technika & 24,4 & 34 & 25,6 & 26,1 \\
\hline średnio-niska technika & 13,8 & 21,3 & 31,3 & 32,1 \\
\hline niska technika & 58,5 & 39,1 & 38,6 & 37,3 \\
\hline udział wyrobów wysokiej techniki w imporcie & 9 & 12,3 & 9,2 & 10,3 \\
\hline udział wyrobów wysokiej techniki w eksporcie & 2,3 & 2,9 & 2,3 & 3,2 \\
\hline
\end{tabular}

Źródło: Nauka i technika w 2002 roku, GUS, Warszawa 2004, s. 162; Nauka i technika w 2005 roku, GUS, Warszawa 2006, s. 214

Przestarzała struktura asortymentowa nie tylko decyduje o niskiej atrakcyjności wyrobów polskiego przemysłu za granicą, ale też nie zaspokaja popytu wewnętrznego na dobra z grupy high tech. Dlatego w obszarze tych produktów niezmiennie utrzymuje się ujemne saldo w obrotach bieżących z zagranicą. Dla porównania należy wspomnieć, że w krajach o największym potencjale technologicznym udział dóbr z grupy wysokiej techniki zarówno w produkcji, jak i eksporcie przekracza 20\% (Nauka... 2006, s. 215).

Ujemne saldo w obrotach z zagranicą dotyczy nie tylko artykułów zaawansowanych technologicznie, ale jest ogólnym problemem polskiej gospodarki. Za jedną z największych porażek transformacji gospodarczej należy uznać ciagły wzrost importochłonności gospodarki: w 2004 r. wartość importu przekroczyła wartość 325 mld zł, co stanowiło prawie 35\% popytu. Jakkolwiek w kilku ostatnich latach obserwuje się pozytywną tendencję w eksporcie, nie ma ona jednak charakteru trwałego, gdyż nie wiąże ze wzrostem konkurencyjności 
technologicznej polskiej gospodarki. Brak konwergencji w zakresie high tech oznacza, że w przypadku pojawienia się tendencji recesyjnych w gospodarce światowej widmo deficytu obrotów bieżących ponownie zagrozi gospodarce.

Procesowi spontanicznego transferu technologii, prowadzącemu do wzrostu efektywności wytwarzania wyrobów tradycyjnych, towarzyszy likwidacja miejsc pracy. Jeśli proces ten nie jest powiązany z ekspansją przemysłów wysokiej techniki, zarówno w zakresie wzrostu ich udziału w produkcji, jak i zatrudnieniu, nieuchronne staje się szybkie narastanie bezrobocia (tab. 3). Brak wizji rozwoju GOW i błędy popełnione w procesie prywatyzacji sprawiły, że odsetek pracujących w dziedzinach technologicznie intensywnych, w obszarze produkcji i usług znacząco odbiega w Polsce od średniej UE-24. Tymczasem w gospodarkach rozwiniętych działy oparte na wiedzy od połowy lat 90. generują większość nowych miejsc pracy. Jest to zjawisko korzystne nie tylko z punktu widzenia poziomu zatrudnienia, ale przede wszystkim jego struktury - większość miejsc pracy w „nowych” sektorach to stanowiska dla wykwalifikowanych pracowników zarządu i kadry naukowo-technicznej (Zakrzewski 2002, s. 73).

Tab. 3. Pracujący według poziomu ,intensywności B+R” w Polsce i w UE

\begin{tabular}{|l|c|c|}
\hline \multirow{2}{*}{ Dziedziny działalności } & \multicolumn{2}{c|}{ Odsetek pracujących } \\
\cline { 2 - 3 } & Polska (2004) & UE-24*(2003) \\
\hline przemysły wysokiej techniki & 0,6 & 1,2 \\
\hline przemysły średnio-wysokiej techniki & 4,6 & 5,4 \\
\hline przemysły średnio-niskiej techniki & 4,8 & 4,3 \\
\hline przemysły niskiej techniki & 11,5 & 6,8 \\
\hline usługi high tech & 2,5 & 3,2 \\
\hline pozostałe usługi oparte na wiedzy & 16,9 & 27,5 \\
\hline pozostałe usługi & 31,4 & 31,7 \\
\hline pozostałe dziedziny & 27,7 & 19,9 \\
\hline
\end{tabular}

*-bez Polski

Źródło: Statistic in Focus, Science and Technology 9-10/2004, Eurostat 2004

Analizując dane z tabeli 3, należy mieć również na uwadze dysproporcje pomiędzy Polską a Unią Europejską nie tylko w zakresie liczby bezrobotnych, ale także zawodowo biernych. Tych ostatnich jest w Polsce jest ponad 7 mln, jeśli uwzględnić ludność w wieku produkcyjnym. Oznacza to, że odsetek społeczeństwa polskiego mający w pracy zawodowej dostęp do najnowszych technologii, a więc również praktyczne kompetencje w tym obszarze, jest znacząco mniejszy niż w krajach rozwiniętych. Ta miara dystansu rozwojowego, dzielącego nasz kraj od „technologicznej czołówki”, pokazuje, że rozwój dziedzin gospodarki opartych na wiedzy może być czynnikiem kreacji miejsc pracy dla rosnącej liczby absolwentów i przyczyni się tym samym do poprawy struktury zatrudnienia. Aby tak się stało, Polsce potrzebna jest strategia prowzrostowa oparta na wzroście produktywności całkowitej poprzez rozwój kapitału intelektualnego i sprawiedliwe nierówności społeczne (Woźniak 2006, s. 13-27). 


\section{PODSUMOWANIE}

Proces przemian gospodarczych zapoczątkowany w Polsce w 1989 roku doprowadził do znaczącego zbliżenia struktury produkcji i zatrudnienia do modelu obowiązującego w krajach rozwiniętych. O ile jednakże generalny kierunek owych zmian należy uznać za pozytywny, ich intensywność w poszczególnych obszarach była zmienna, skutkiem czego zasadniczy ich cel w postaci wzrostu konkurencyjności nie został osiagnięty.

Za największy sukces 18 lat transformacji należy uznać realizację procesu przekształceń własnościowych, zmierzających do ekspansji prywatnej przedsiębiorczości, będącej warunkiem sprawnego działania mechanizmu rynkowego. Znaczenie tych zmian wynika z faktu, iż stanowią one impuls do dalszych przeobrażeń strukturalnych, które są nieodłącznym elementem procesu gospodarowania w warunkach swobody działalności gospodarczej i konkurencji. Należy przy tym podkreślić, iż pozytywna ocena procesu prywatyzacji opiera się na jej efektach ilościowych, rozumianych jako zmiana udziałów sektora publicznego i prywatnego $\mathrm{w}$ gospodarce. Jest to zatem ocena cząstkowa, nie uwzględniająca jakościowych aspektów tego procesu, równie ważnych ze względów ekonomicznych i społecznych.

Za największe niepowodzenie procesu restrukturyzacji należy natomiast uznać zaniedbania w zakresie modernizacji technologicznej i promowania innowacyjności podmiotów gospodarczych. Jednocześnie jest to zaniedbanie obciążające w pierwszej kolejności politykę państwa. O ile bowiem zasadność bezpośredniej ingerencji państwa w proces przemian strukturalnych jest kwestią dyskusyjną, o tyle konieczność aktywnej roli władzy publicznej w takich dziedzinach, jak innowacyjność i rozwój kapitału ludzkiego, nie budzi żadnych wątpliwości w świecie ekonomistów. Konsekwencje niskiej konkurencyjności są natomiast daleko idące: skutkuje ona nie tylko niską atrakcyjnością oferty produktowej za granicą, ale również wysoką skłonnością gospodarki do importu, w znacznej mierze konsumpcyjnego. Ujemne saldo w obrotach z zagranicą stanowi natomiast istotną barierę dla wzrostu gospodarczego, a także wzrostu zatrudnienia i kształtowania właściwej jego struktury.

\section{Literatura}

Bałtowski M., Miszewski M., 2006, Transformacja gospodarcza w Polsce, PWN, Warszawa

Chmiel I., 1999, Problemy statystycznego pomiaru i analizy tendencji rozwojowych sektora prywatnych przedsiębiorstw w Polsce w latach 1990-1999, „,Raporty CASE”, nr 24

Kaczmarek J., Krzemiński P., Litwa P., Szymla W., 2005, Procesy zmian w okresie transformacji systemowej. Prywatyzacja, restrukturyzacja, rynek kapitałowy, Wydawnictwo AE, Kraków

Lipowski A., 1994, Przemiany strukturalne, Wydawnictwo Naukowe Semper, Warszawa

Nauka i technika w 2005 roku, GUS, Warszawa 2006

Macias J., 2006, Zmiany strukturalne w przemyśle w Polsce, „Ekonomika i Organizacja Przedsiębiorstwa", nr 7

Turowski K., 2006, Sektor wysokiej techniki jako czynnik rozwoju kapitału ludzkiego - implikacje dla konkurencyjności polskiej gospodarki, [w:] Kapitat ludzki w gospodarce opartej na wiedzy, red. D. Kopycińska, Katedra Mikroekonomii, Uniwersytet Szczeciński, Szczecin

Woźniak M.G., 2006, Strategiczne i instytucjonalne wyzwania dla Polski w kontekście globalizacji i regionalizacji, [w:] Nierówności społeczne a wzrost gospodarczy. Problemy globalizacji i regionalizacji, cz. 2, red. M.G. Woźniak, Uniwersytet Rzeszowski, Katedra Teorii Ekonomii, Rzeszów, nr 9

Zakrzewski W., 2002, Transformacja zatrudnienia w Unii Europejskiej, „Wiadomości Statystyczne”, nr 3 


\section{Structural change Polish economy after 1990 year}

The author of article analyses in case of transformation the changes of subjective structure, production and technological Polish economy. He establishes on basis this analysis the successes and failure of restructuring. In article was postulated the acceleration of technological convergence, which would make possible the expansion of economy based on knowledge. It is her condition economic growth steered on growth of productiveness across development of human capital strategy and fair social unevenness. 